\title{
THE APPLICATION OF STRATEGY-BASED INSTRUCTIONS TO TEACH WRITING TO FIRST-YEAR ENGLISH MAJORED STUDENTS
}

\author{
Duong Thu Mai* \\ Faculty of English Language Teacher Education, VNU University of Languages and International \\ Studies, Pham Van Dong, Cau Giay, Hanoi, Vietnam
}

Received 12 February 2018

Revised 17 March 2018; Accepted 30 March 2018

\begin{abstract}
Learning strategies (LS) have been a salient field of study in English Language Teaching (ELT) globally for the last few decades. In Vietnam, however, while the role of teachers is undeniable and teachers' action research has proliferated exponentially, the unequal number of studies on a subject of equal importance, i.e. the local learners' learning methods, is conspicuous. Additionally, the "how" is as important as the "what", especially for the first-year university students, who experience a great change of learning and teaching methods when entering universities. This study examines the range of writing LS used by 50 first-year English majored students at a teacher training university in Vietnam, and the differences between more and less skilled students in writing, after being instructed on LS for one year. The study found four groups of LS of different popularity, and significant variations in LS use between the two groups of students.
\end{abstract}

Keywords: strategy training, learning strategy, English as a foreign language (EFL) writing

\section{Introduction}

If students are asked about their LS, they often give various answers and even one student can change the answers in different interview sessions. This situation is particularly true in writing, in which the students' slow progress signifies it as the most difficult skill to teach and to learn. For those reasons, in this study, the significance of LS to the first year English majored students in learning to write in English will be addressed. To be specific, the study answers two research questions:

1. What is the range of LS that the firstyear students apply in writing?

2. What LS are used by the more and less skilled student writers?

\section{Theoretical backgrounds}

\subsection{Learning strategies: Definitions and features}

\footnotetext{
* Tel.: 84-1669686968

Email: duongthumai@yahoo.com
}

A large number of studies have been conducted on the good language learners, many of which have indicated that these learners possess special learning strategies. However, it is not simple to define the term "learning strategies". Ellis (1980) pointed out that there was no agreement on the essence, the quantity and the contents of LS. In foreign language teaching, while the initial definitions of LS were much affected by behaviourism, i.e. LS are techniques or devices learners use to acquire the language (Rubin, 1975), the newer definitions took a more "mentalist" approach. According to Cohen, "learning strategies are the conscious thoughts and behaviors used by learners with the explicit goals of improving their knowledge and understanding of the target language" (1998, p.68). It is of great importance to note the term "conscious", which indicates learners' awareness of all the processes/strategies available before 
choosing the best one. This element of freedom in choosing is the prerequisite factor identifying learning strategies.

Nunan, however, is not so much concerned about the consciousness in learners' choice. As for him, learning strategies are "the mental processes which learners employ to learn and use the target language" (Nunan, 1991:168) or "the specific mental procedures for gathering, processing, associating, categorizing, rehearsing, and retrieving information or patterned skills" (Nunan, 1988: 7). He also considers learning strategies the act of learning viewed at micro level, or one unit of learning.

As for this study, the most complete definition of learning strategies is developed by Chamot and O'Malley, stating that learning strategies are special ways of processing information which help enhance comprehension, learning and retention of the information (Chamot and O'Malley, 1996). They share Nunan's definition, that learning strategies are procedures/steps undertaken by the learners in order to make their own language learning as effective as possible (O’Malley \& Chamot, 1990). LS are strongly linked to the underlying learning styles of learners whether they are called "steps', "processes', " procedures” or 'ways".

\subsection{Strategy training approaches}

Strategies training explicitly informs students on how, when, and why strategies are used to facilitate their efforts at learning and using a foreign language (Cohen, 1998). Cohen also summarized that all the researches on strategies training more or less fall into two main frameworks:

- Pearson and Dole's approach: this is mainly for training a specific strategy in teaching the first language with the following steps:

+ the teacher demonstrates the strategy with direct explanation of the strategy's use and importance
+ learners receive guided practice with the strategy

+ the teacher helps the learners to identify the strategy and decide when it may be used + learners practice the strategy independently

+ learners apply the strategy to new tasks

- Oxford et al.'s approach

Many strategies are trained in foreign language learning situations. For an instance, learners are asked to do a task without any strategy training, then they can discuss how they have done the task and how these ways facilitate their learning. The teacher praises the good strategies and suggests more useful strategies. The learners may suggest ways to integrate these strategies into their learning, practice the new strategies before the teacher shows how the strategies can be transferred to other tasks, provides tasks and asks the learners to choose appropriate LS and helps students to evaluate the success of the strategies.

- Chamot and O'Malley added another approach of strategy training: after assessing the learners' use of strategies initially, the teacher can conduct a training programme based on the following eight steps:

Step 1. Determine the learners' needs and the time available.

Step 2. Selects the relevant, useful, easy, valuable strategies to learning

Step 3. Consider the integration of strategies training into authentic language learning situations

Step 4. Consider motivational issues

Step 5. Prepare materials and activitie in a way that supplement strategies training, and develop more materialswhen necessary

Step 6. Conduct "Completely Informed Training": the learners are provided with all necessary knowledge of the LS

Step 7. Evaluate the strategy training 
Step 8. Revise the strategy training:teachers make some adjustments for the programme, which will trigger a new strategy training circle to restart.

(Chamot and O'Malley, 1990)

The three approaches/procedures can be realized in several ways such as General study skills training, Awareness training, Peer tutoring (the learners are arranged to meet regularly and discuss about the language LS they typically use), or the strategies can be inserted into textbooks. Strategy-based instruction (SBI) is also a recently mentioned alternative. In light of the learner-centred approach, SBI contain both explicit and implicit strategy training. The teacher may follow these steps:

$\circ$ describe, model and give examples of potentially useful strategies.

- elicit additional examples from students based on the students' own learning experiences.

- lead small-group/whole-class discussion about strategies.

- encourage their students to experiment with a broad range of strategies.

○ integrate strategies into everyday class materials, explicitly and implicitly embedding them into the language task to provide contextual strategy practice.

(Cohen and Weaver, 1998, p.81)

Thus, the teacher's role in SBI is that of a diagnostician of learners' current strategies, a learner trainer, a coach, a coordinator of learners' learning process, a language learner in order to be able to sympathize with the learners' status in the classroom (both good and bad moments), and lastly, as a researcher who judges him/herself on all the process mentioned so far.

It is important to note down some important empirical studies realized within these three approaches. One study involving the training of strategies for listening was developed by Fujiwara in 1990 for 45 Japanese learners of English, finding that $80 \%$ of the students found that their listening skills were improved and $16 \%$ felt that the training was extremely helpful. Another study on listening strategies was by Thompson and Robin (1996) with Russian learners of English in a true experimental research. It was found that the experimental group did better on a test of video comprehension. In training speaking strategies, Nunan (1996) also studied 15 strategies with 60 undergraduates in a compulsory English to Arts Students course. There were two experimental classes and two controlled ones, the formers received key learning and strategies incorporated in their language teaching program. The students' motivation and strategy use were assessed in a pre-test post-test basis. The study found that the students' motivation was improved more significantly in the experimental groups than in the controlled groups, as well as the utility of strategies. In general, most strategy training studies yield positive results.

\subsection{Writing learning strategies}

Chamot and O'Malley are two authors who have extensively researched into the field of LS. The strategies they have found for learning writing include 44 items, which will be used as the framework for SBI and the questionnaires in this study.

\section{A. Memory strategies}

A.1. Placing new words into a context

A.2. Using key words

A.3. Using mechanical techniques

\section{B. Cognitive strategies}

\section{B.1. Repeating}

B.2. Formally practicing with sounds and writing system

B.3. Recognising and using formulas and patterns

B.4. Recombining 
B.5. Practising naturalistically

B.6. Using resources for receiving and sending messages

B.7. Reasoning deductively

B.8. Translating

B.9. Transferring

B.10. Taking notes

B.11. Summarising

B.12. Highlighting

\section{Compensation strategies}

C.1. Selecting the topic

C.2. Adjusting or approximating the message

C.3. Coining words

C.4. Using a circumlocution or a synonym

\section{Metacognitive strategies}

D.1. Overviewing and linking with already known materials

D.2. Paying attention

D.3. Finding out about language learning

D.4. Organizing

D.5. Setting goals and objectives

D.6. Identifying the purposes of a language task

D.7. Planning for a language task

D.8. Seeking practice opportunities

D.9. Self-monitoring

D.10. Self-evaluating

\section{E. Affective strategies}

E.1. Using progressive relaxation, deep breathing, or meditation

E.2. Using music

E.3. Using laughter

E.4. Making positive statements

E.5. Taking risks wisely

E.6. Rewarding yourself

E.7. Listening to your body

E.8. Using a checklist

E.9. Writing a language learning diary

E.10. Discussing your feelings with someone else

\section{F. Social strategies}

F.1. Asking for correction

F.2. Cooperating with peers

F.3. Cooperating with proficient users of the language

F.4. Developing cultural understanding

F.5. Becoming aware of others' thoughts and feelings

Basing on this repertoire of LS for writing, we studied the strategies the targeted students apply in their learning how to write English at the first year.

\section{The study}

\subsection{Participants of the study}

Two classes of first-year English majored students $(\mathrm{N}=50,4$ males and 46 females $)$ at a language teacher training university in Vietnam were sampled with random cluster sampling from 17 first-year mainstream classes and involved in this study. It was only possible for the researcher to conduct the study with two classes so that she could teach the class herself and monitor the SBI procedure. The students' English proficiency may be roughly attributed to B1 (CEFR) as they have passed the university entrance exam. The students learnt the coursebook From writing to composing (Ingram and King, 2004), and the teaching methods for writing skills combines product-oriented approach and process-oriented one. The students' scores for the first composition in the first semester was taken as the pre-test scores and their scores in the final test was taken as the post-test scores.

\subsection{The intervention: Strategies-based} Instructions-Procedures

The procedures and schedules for completing SBI are presented in brief as follows:

\section{Determine students'needs}


The teacher and students talk about the prior teaching and learning methods in writing skills. Advantages as well as disadvantages of these methods are discussed, along with the teachers' presentation of LS for writing.

Raise awareness on 44 strategies for learning writing by giving strategy inventories to students, giving explanations and checking comprehension

Explicit initial training is given to student in a workshop. First, they are to read the list of LS useful for writing skills (previous section). The teacher then asks them to work in groups or pairs to discuss how they understand each strategy and then correct their comprehension.

Pre-test to check the original writing proficiency and frequency of using LS of students (using a writing task)

Immediately after the 45-minute writing test, the students were asked to complete the questionnaire with $44 \mathrm{LS}$.

Train various strategies based on the course book

All the LS in the Strategy Inventory were taught to students through tasks and exercises in the coursebook in prepared lesson plans.

\section{Limit the number of $L S$ to train}

A class discussion is held in order for the students to state the LS they want to be more thoroughly trained in the second semester. The teacher then bases on this and the content of the coursebook for the second semester to decide the 25 LS to be trained.

Continue training the 25 short-listed LS explicitly and implicitly

All the lessons in the second-semester coursebook are planned according to the LSoriented approach. The teacher's instructions for coursebook tasks compulsorily include remarks and exemplification on the use of LS. Moreover, the LS are trained in the suitable stage of writing as presented in the previous section.
Post-test on the students' writing proficiency and frequency of using $L S$

The students took the official final test in which they had to perform a writing task. Their scores in this task were used as their post test results and to classify writers. They also did the second questionnaire on LS frequency, with $25 \mathrm{LS}$.

\subsection{Instrumentation and data collection}

The first instrument for collecting data is two Strategy Inventories; the first one includes all the 44 strategies for writing composed by Chamot and O'Malley (section 2.3 above) and the second one includes 25 short-listed strategies. For each of these inventories, the students were required to choose a frequency that reflected their use of each strategy from Always to Never.

Other instruments are the 2 fulfilled writing tasks of students, one at the beginning of semester one (pre-test) and the other at the end of semester two (post-test). The questions in the tests have undergone strict evaluation of the first year teachers because the scores are taken as midterm and final term scores. The criteria for distinguishing more and less skilled students for research question 2 were: skilled students are those with post-test score over 7. The others were considered less skilled. According to the teachers at the research site, 7 was often the score which represents the required outcome of the first year students (B2, CEFR). The description of 7 in the rubrics represent the B2 level description. The scoring criteria in this study were as in the formal scoring instruments for first year students' writing at the study stite, consisting of five criteria named content development, coherence and organization, cohesion, lexical range and accuracy, grammatical range and accuracy. The researcher and a first-year teacher scored the writings twice before coming to the conclusion on the students' final scores. 


\section{Data analysis}

In order to compare task performances, after all the tests were scored, means and standard deviation of each test were calculated to find out whether the students generally improved after one year of training. Secondly, basing on the post-test, the two groups of students: skilled and less skilled, were identified before their frequencies of using LS were analyzed. The differences between two groups' use of LS were revealed through Chisquare test, a popular test for comparing frequencies. Critical value for Chi-square test was determined at 0,05 , which means we accepted only $5 \%$ that the differences can occur by chance. If the $\mathrm{x}^{2}$ value we find is higher than the $\mathrm{x}^{2}$ with critical value $=$ 0,05 and a certain degree of freedom, we can be sure of the differences in two groups' frequency uses.

\section{Results}

\section{LS use for writing by first-year students}

The most apparent feature is that the students chose to use a large number of strategies sometimes : for 18 in 44 strategies, the rate for sometimes is above $30 \%$, the highest of which is $54 \%$ in $\mathrm{F} 2$, and $50 \%$ in $\mathrm{A} 1$ and $\mathrm{C} 1$. Meanwhile, the rates for always and never in using these strategies are insignificant. Another frequency at which the students tent to use many LS is "usually", the most common frequency in using 16 strategies. Not many strategies were used at the highest frequency, except in some cases: B3, B8, B12, D1, D6. Specially, in B8, $48 \%$ of the students reported they "always" used, while the number fell steeply for the other frequencies: usually (26), sometimes (18), hardly ever (8) and never (0). On the contrary, there are some strategies which very few students always use: B4, C3, B11, E3, F2, F5, B10.
The strategies which are the most rarely used are B2, B11, D5, D8, E1, E8 and F5 and there are more students who never used B2, B5, B11, C4, E1, E2, E3, E9 than those who used these strategies often. More detailed discussion of the popularity of strategies are presented later.

Comparison of pre-test and post-test performance

Table 1. Pre-test and post-test performance

\begin{tabular}{|c|c|c|}
\hline Descriptive statistics & Pre-test & Post-test \\
\hline Mean & 6.958 & 7.674 \\
\hline Mode & 7 & 7.9 \\
\hline Median & 7 & 7.8 \\
\hline Low & 3 & 6 \\
\hline High & 9 & 8.8 \\
\hline Range & 6 & 2.8 \\
\hline Standard Deviation & 1.30 & 0.63 \\
\hline
\end{tabular}

Table 1 reports the better performance of students in the post test compared to the pre-test. The mean of students' scores in the post test was 0.7 point higher than in the pretest. All the indices of the post-tests are also higher, except for the standard deviation, which is a positive evidence for the students' improvement and narrower range of scores in writing after SBI.

\section{Students' use of LS after SBI}


Table 2. Chi-square test of more skilled and less skilled learners' frequencies of using LS after SBI

\begin{tabular}{|c|c|c|c|c|c|c|c|c|c|c|c|c|c|}
\hline \multirow{2}{*}{\multicolumn{2}{|c|}{ Strategy }} & \multicolumn{2}{|c|}{ Always } & \multicolumn{2}{|c|}{ Usually } & \multicolumn{2}{|c|}{ Sometimes } & \multicolumn{2}{|c|}{$\begin{array}{c}\text { Hardly } \\
\text { ever }\end{array}$} & \multicolumn{2}{|c|}{ Never } & \multirow[t]{2}{*}{ Total } & $\begin{array}{c}\text { Chi-square } \\
\text { test }\end{array}$ \\
\hline & & $\mathrm{F}$ & $\%$ & $\mathrm{~F}$ & $\%$ & $\mathrm{~F}$ & $\%$ & $\mathrm{~F}$ & $\%$ & $\mathrm{~F}$ & $\%$ & & \\
\hline \multirow[t]{3}{*}{ A1 } & More skilled & 6 & 17 & 18 & 51 & 7 & 20 & 3 & 9 & 1 & 3 & 35 & $x^{2}=10,93$ \\
\hline & Less skilled & 2 & 13 & 3 & 20 & 3 & 20 & 2 & 13 & 5 & 33 & 15 & $\mathrm{df}=4$ \\
\hline & & 8 & & 21 & & 10 & & 5 & & 6 & & 50 & \\
\hline \multirow[t]{3}{*}{$\mathrm{A} 2$} & More skilled & 3 & 9 & 12 & 34 & 12 & 34 & 5 & 14 & 4 & 11 & 35 & $x^{2}=2,40$ \\
\hline & Less skilled & 0 & 0 & 5 & 33 & 4 & 27 & 4 & 27 & 2 & 13 & 15 & $\mathrm{df}=4$ \\
\hline & & 3 & & 17 & & 16 & & 9 & & 6 & & 50 & \\
\hline \multirow[t]{3}{*}{ B1 } & More skilled & 0 & 0 & 10 & 29 & 15 & 43 & 8 & 23 & 2 & 6 & 35 & $x^{2}=2,78$ \\
\hline & Less skilled & 0 & 0 & 6 & 40 & 3 & 20 & 4 & 27 & 2 & 13 & 15 & $\mathrm{df}=3$ \\
\hline & & 0 & & 16 & & 18 & & 12 & & 4 & & 50 & \\
\hline \multirow[t]{3}{*}{ B3 } & More skilled & 9 & 26 & 24 & 69 & 1 & 3 & 1 & 3 & 0 & 0 & 35 & $\mathrm{x}^{2}=18,34$ \\
\hline & Less skilled & 2 & 13 & 4 & 27 & 5 & 33 & 3 & 20 & 1 & 7 & 15 & $\mathrm{df}=4$ \\
\hline & & 11 & & 28 & & 6 & & 4 & & 1 & & 50 & \\
\hline B4 & More skilled & 19 & 54 & 8 & 23 & 6 & 17 & 1 & 3 & 1 & 3 & 35 & $x^{2}=6,18$ \\
\hline & Less skilled & 4 & 27 & 4 & 27 & 7 & 47 & 0 & 0 & 0 & 0 & 15 & $\mathrm{df}=4$ \\
\hline & & 23 & & 12 & & 13 & & 1 & & 1 & & 50 & \\
\hline B5 & More skilled & 4 & 11 & 11 & 31 & 12 & 34 & 6 & 17 & 2 & 6 & 35 & $x^{2}=2,62$ \\
\hline & Less skilled & 0 & 0 & 6 & 40 & 4 & 27 & 4 & 27 & 1 & 7 & 15 & $\mathrm{df}=4$ \\
\hline & & 4 & & 17 & & 16 & & 10 & & 3 & & 50 & \\
\hline B6 & More skilled & 4 & 11 & 11 & 31 & 13 & 37 & 3 & 9 & 4 & 11 & 35 & $x^{2}=10,32$ \\
\hline & Less skilled & 3 & 20 & 3 & 20 & 1 & 7 & 6 & 40 & 2 & 13 & 15 & $\mathrm{df}=4$ \\
\hline & & 7 & & 14 & & 14 & & 9 & & 6 & & 50 & \\
\hline B8 & More skilled & 2 & 6 & 7 & 20 & 8 & 23 & 14 & 40 & 4 & 11 & 35 & $x^{2}=9,62$ \\
\hline & Less skilled & 4 & 27 & 6 & 40 & 3 & 20 & 1 & 7 & 1 & 7 & 15 & $\mathrm{df}=4$ \\
\hline & & 6 & & 13 & & 11 & & 15 & & 5 & & 50 & \\
\hline $\mathrm{B} 10$ & More skilled & 0 & 0 & 12 & 34 & 10 & 29 & 8 & 23 & 5 & 14 & 35 & $x^{2}=14,89$ \\
\hline & Less skilled & 2 & 13 & 0 & 0 & 4 & 27 & 2 & 13 & 7 & 47 & 15 & $\mathrm{df}=4$ \\
\hline & & 2 & & 12 & & 14 & & 10 & & 12 & & 50 & \\
\hline $\mathrm{C} 2$ & More skilled & 4 & 11 & 16 & 46 & 9 & 26 & 5 & 14 & 1 & 3 & 35 & $x^{2}=4,01$ \\
\hline & Less skilled & 1 & 7 & 4 & 27 & 4 & 27 & 4 & 27 & 2 & 13 & 15 & $\mathrm{df}=4$ \\
\hline & & 5 & & 20 & & 13 & & 9 & & 3 & & 50 & \\
\hline D1 & More skilled & 20 & 57 & 11 & 31 & 4 & 11 & 0 & 0 & 0 & 0 & 35 & $x^{2}=10,86$ \\
\hline & Less skilled & 3 & 20 & 7 & 47 & 2 & 13 & 0 & 0 & 3 & 20 & 15 & $\mathrm{df}=3$ \\
\hline & & 23 & & 18 & & 6 & & 0 & & 3 & & 50 & \\
\hline D2 & More skilled & 0 & 0 & 4 & 11 & 13 & 37 & 11 & 31 & 7 & 20 & 35 & $x^{2}=3,83$ \\
\hline & Less skilled & 0 & 0 & 3 & 20 & 4 & 27 & 2 & 13 & 6 & 40 & 15 & $\mathrm{df}=3$ \\
\hline & & 0 & & 7 & & 17 & & 13 & & 13 & & 50 & \\
\hline D5 & More skilled & 4 & 11 & 7 & 20 & 7 & 20 & 12 & 34 & 5 & 14 & 35 & $x^{2}=7,12$ \\
\hline & Less skilled & 0 & 0 & 1 & 7 & 6 & 40 & 3 & 20 & 5 & 33 & 15 & $\mathrm{df}=4$ \\
\hline & & 4 & & 8 & & 13 & & 15 & & 10 & & 50 & \\
\hline D6 & More skilled & 4 & 11 & 16 & 46 & 7 & 20 & 2 & 6 & 6 & 17 & 35 & $x^{2}=1,15$ \\
\hline & Less skilled & 2 & 13 & 7 & 47 & 2 & 13 & 2 & 13 & 2 & 13 & 15 & $\mathrm{df}=4$ \\
\hline & & 6 & & 23 & & 9 & & 4 & & 8 & & 50 & \\
\hline
\end{tabular}




\begin{tabular}{|c|c|c|c|c|c|c|c|c|c|c|c|c|c|}
\hline D7 & More skilled & 5 & 14 & 18 & 51 & 7 & 20 & 4 & 11 & 1 & 3 & 35 & $x^{2}=12,29$ \\
\hline & Less skilled & 0 & 0 & 2 & 13 & 6 & 40 & 5 & 33 & 2 & 13 & 15 & $\mathrm{df}=4$ \\
\hline & & 5 & & 20 & & 13 & & 9 & & 3 & & 50 & \\
\hline \multirow[t]{3}{*}{ D8 } & More skilled & 0 & 0 & 4 & 11 & 12 & 34 & 16 & 46 & 3 & 9 & 35 & $\mathrm{x}^{2}=0,75$ \\
\hline & Less skilled & 0 & 0 & 2 & 13 & 6 & 40 & 5 & 33 & 2 & 13 & 15 & $\mathrm{df}=3$ \\
\hline & & 0 & & 6 & & 18 & & 21 & & 5 & & 50 & \\
\hline \multirow[t]{3}{*}{ D9 } & More skilled & 5 & 14 & 16 & 46 & 5 & 14 & 7 & 20 & 2 & 6 & 35 & $x^{2}=4,77$ \\
\hline & Less skilled & 1 & 7 & 3 & 20 & 4 & 27 & 5 & 33 & 2 & 13 & 15 & $\mathrm{df}=4$ \\
\hline & & 6 & & 19 & & 9 & & 12 & & 4 & & 50 & \\
\hline \multirow[t]{3}{*}{ D10 } & More skilled & 6 & 17 & 21 & 60 & 5 & 14 & 0 & 0 & 3 & 9 & 35 & $x^{2}=11,48$ \\
\hline & Less skilled & 0 & 0 & 6 & 40 & 4 & 27 & 3 & 20 & 2 & 13 & 15 & $\mathrm{df}=4$ \\
\hline & & 6 & & 27 & & 9 & & 3 & & 5 & & 50 & \\
\hline \multirow[t]{3}{*}{$\mathrm{E} 4$} & More skilled & 4 & 11 & 8 & 23 & 9 & 26 & 9 & 26 & 5 & 14 & 35 & $x^{2}=2,19$ \\
\hline & Less skilled & 0 & 0 & 3 & 20 & 4 & 27 & 5 & 33 & 3 & 20 & 15 & $\mathrm{df}=4$ \\
\hline & & 4 & & 11 & & 13 & & 14 & & 8 & & 50 & \\
\hline \multirow[t]{3}{*}{ E5 } & More skilled & 1 & 3 & 4 & 11 & 12 & 34 & 8 & 23 & 10 & 29 & 35 & $x^{2}=15,91$ \\
\hline & Less skilled & 1 & 7 & 9 & 60 & 4 & 27 & 1 & 7 & 0 & 0 & 15 & $\mathrm{df}=4$ \\
\hline & & 2 & & 13 & & 16 & & 9 & & 10 & & 50 & \\
\hline \multirow[t]{3}{*}{ E6 } & More skilled & 3 & 9 & 8 & 23 & 13 & 37 & 5 & 14 & 6 & 17 & 35 & $\mathrm{x}^{2}=2,08$ \\
\hline & Less skilled & 0 & 0 & 3 & 20 & 8 & 53 & 2 & 13 & 2 & 13 & 15 & $\mathrm{df}=4$ \\
\hline & & 3 & & 11 & & 21 & & 7 & & 8 & & 50 & \\
\hline \multirow[t]{3}{*}{$\mathrm{F} 1$} & More skilled & 4 & 11 & 16 & 46 & 11 & 31 & 2 & 6 & 2 & 6 & 35 & $x^{2}=1,10$ \\
\hline & Less skilled & 1 & 7 & 7 & 47 & 4 & 27 & 1 & 7 & 2 & 13 & 15 & $\mathrm{df}=4$ \\
\hline & & 5 & & 23 & & 15 & & 3 & & 4 & & 50 & \\
\hline \multirow[t]{3}{*}{$\mathrm{F} 2$} & More skilled & 0 & 0 & 20 & 57 & 11 & 31 & 3 & 9 & 1 & 3 & 35 & $x^{2}=5.96$ \\
\hline & Less skilled & 2 & 13 & 6 & 40 & 4 & 27 & 2 & 13 & 1 & 7 & 15 & $\mathrm{df}=4$ \\
\hline & & 2 & & 26 & & 15 & & 5 & & 2 & & 50 & \\
\hline \multirow[t]{3}{*}{ F3 } & More skilled & 5 & 14 & 15 & 43 & 11 & 31 & 2 & 6 & 2 & 6 & 35 & $x^{2}=13,50$ \\
\hline & Less skilled & 0 & 0 & 1 & 7 & 8 & 53 & 5 & 33 & 1 & 7 & 15 & $\mathrm{df}=4$ \\
\hline & & 5 & & 16 & & 19 & & 7 & & 3 & & 50 & \\
\hline \multirow[t]{3}{*}{$\mathrm{F} 4$} & More skilled & 0 & & 8 & & 16 & & 10 & & 3 & & 35 & $x^{2}=5,34$ \\
\hline & Less skilled & 0 & & 0 & & 6 & & 8 & & 1 & & 15 & $\mathrm{df}=3$ \\
\hline & & 0 & & 8 & & 22 & & 18 & & 4 & & 50 & \\
\hline
\end{tabular}

Table 2 demonstrates clearly the differences in LS use between effective and ineffective writers. The alpha decision level for this study (p), as previously mentioned, is 0,05 and regarding this data and the available degrees of freedoms, the critical value for $\mathrm{x}^{2}$ is 9,4877 for $d f=4$ and 7,4187 for $d f=3$ (according to the critical value of $\mathrm{x}^{2}$ (Pearson and Hartley,1963)). Thus, the differences between effective an ineffective writers were seen in the use of the following strategies: A1, B3, B6, B8, B10, D1, D7, D10, E5, F3 because the calculated value of $x^{2}$ in these comparison of frequencies are higher than the two values above respectively. The highest values were found in E5, B3, B10 and F3, which means there is a dramatical difference between the two groups of learners' frequency of using these strategies. On the contrary, the two groups' use of strategies is rather similar in A2, B1, D2, D6, D8, E6 as can be seen from the very low calculated value of $\mathrm{x}^{2}$. These differences will only be significant in studies with alpha decision level of 0,20 , where there 
is a great risk that the differences occur by chance.

\section{Discussion of research questions}

\section{Research question 1}

Looking into trends of using strategies, we can classify students' use of all the strategies into four more specific groups. The most popular strategies include the strategies which the students used the most (Recognising and using formulas and patterns; Translating; Highlighting; Overviewing and linking with already known materials; Identifying the purposes of a language task). The fairly popular strategies are Using key words, Using mechanical techniques; Recombining; Using resources for receiving and sending messages, Reasoning deductively, Transferring; Taking notes; Selecting the topic; Adjusting or approximating the message, etc. ). Group 3 - Fairly unpopular strategies, consists of Placing new words into a context, Repeating, Setting goals and objectives, Making positive statements, Using a checklist, Cooperating with proficient users of the language, etc. Unpopular strategies, the last group, are: Formally practicing with sounds and writing system. Summarizing, Using progressive relaxation, deep breathing, or meditation, Using music or a diary.

\section{Research question 2}

A comparison was made to tract the differences between effective writers and ineffective ones' use of LS. The thorough analysis tested by Chi-square test has revealed ten strategies in which the two groups of writers distinctively applied. They are:

1. Placing new words into a context

2. Recognising and using formulas and patterns

3. Using resources for receiving and sending messages

4. Translating
5. Taking notes

6. Overviewing and linking with already known materials

7. Planning for a language task

8. Self-evaluating

9. Taking risks wisely

10. Cooperating with proficient users of the language

For such difficult strategies as selfevaluating, taking risks, using resources for sending and receiving message, it is comprehensible why there are differences between two groups of writers in using LS. However, with other simpler strategies which were trained fairly regularly, these results came as a surprise.

With the first two strategies in this list, better student writers claimed that imitating was a good way to learn production skills such as writing or speaking, also good methods to remember new words and structures. Meanwhile, the less skilled said they had problems using these strategies such as imprecise use of patterns leading to mistakes, or not being in the habit of using strategies while concentrating in the task. We supposed these problems resulted from the students' carelessness and inautomatic use of strategies, which will be solved with more practice.

There are clear differences in the use of translating as a support for writing as well. While some learners claimed that this strategy helped them to express themselves better when they did not know how to express in English way, others considered this a cause of mistakes because of the differences between English and Vietnamese. Another surprising difference lay in the use of brainstorming (or overviewing and linking with already known materials). This strategy has been one of the most intensively trained one in SBI. Practice activities were provided every lessons. However, there were still learners who considered this a waste of time, especially in 
test situations, which was justified by the lack of time. As for us, it was not the lack of time which counted, but it was the fact that using the strategy has not become a habit to them.

Cooperating with good learners also turned out to be uneasy. With inferiority and introvertness, a limited number of students still did not take the advantage of this strategy.

To sum up, the data have revealed that the use of some strategies contributes to the better writing results of the first-year students while the use of others obviously lead to lower scores.

\section{Conclusion}

The findings of the study highlight that after one year, the students generally improved their writing performance and divided themselves into two groups of writers: effective group and ineffective group, with each preferring some strategies. The effective writers frequently use such strategies as placing new words into a context, recognizing and using formulas and patterns, using resources for receiving and sending messages, overviewing and linking with already known materials, planning for a language task, self-evaluating and cooperating with proficient users of the language. Meanwhile, the increased use of the three strategies: translating, taking notes and taking risks in writing without the fear of making mistakes account for the poor performance of ineffective writers. Of all these strategies, some have been used more often than at the beginning of the year while some have lost their popularity. In other words, the students' awareness of the strategies' effect has been altered. In general, the study succeeded in completing the objectives which we had set out at the introductory stage. However, we could safely say that we only scattered the seeds of LS to the students, who then worked on them and we finally helped them collect the results. These results are their experience and can be effective for their own use in the future.
The study yields some significant implications for writing teachers and EFL teachers in general. First of all, SBI as a program of teaching strategies to students really proved its effects. Whether the relation between frequency of using LS and the students' is not linear, statistics analysis results still strongly suggest the integration of the strategies into the writing curriculum. Besides, the realization of the study has strengthened the orientation and proved the practicality of learner-centred approach in teaching English. In fact, the students have enjoyed great freedom and autonomy through discussing with their peers and their teachers about what to learn and how to learn in SBI. Materials for learning have always been adjusted with regards to learners' needs.

\section{References}

Chamot, A. \& O’Malley, J. (1996). The Cognitive Academic Language Learning Approach: A Model for Linguistically Diverse Classrooms. The Elementary School Journal, 96(3), 259-273.

Cohen, A. D. \& Weaver, S. J. (1998). Strategies-based instruction for second language learners. In W.A. Renandya \& G.M. Jacobs (Eds.), Learners and language learning (pp.1-25). Anthology Series 39. Singapore: SEAMEO Regional Language Centre.

Ellis, R. (1980). Classroom Interaction and its Relation to Second Language Learning. RELC Journal, 11(2), 29-48.

Fujiwara, B. (1990). Learner training in listening strategies. JALT Journal, 12(2), 203-217.

Nunan, D. (1991). Language teaching methodology. London: Prentice Hall International,

Nunan, D. (1988). Syllabus design. Oxford: Oxford University Press,

Nunan, D. (1996). Learner strategy training in the classroom: An action research study. TESOL Journal, 6(1), 35-41.

Nunan, D.(1997). Does learner strategy training make a difference? Lenguas Modernas, 24, 123-142.

O'Malley, J \& Chamot, A. (1990). Learning strategies in second language acquisition. Cambridge University: CUP.

Rubin, J. (1975). What the "Good Language Learner" Can Teach Us. TESOL Quarterly, 9(1).

Thompson, I. \& Rubin, J. (1996). Can strategy instruction improve listening comprehension? Foreign Language Annals, 29(3), 331-342. 


\title{
ÁP DỤNG CHƯƠNG TRÌNH HƯỚNG DÃ̃N CHIẾN LƯợC HỌC CHO SINH VIÊN NĂM THÚ NHẤT CHUYÊN NGÀNH TIẾNG ANH TRONG MÔN VIẾT
}

\author{
Dương Thu Mai \\ Khoa Su phạm tiếng Anh, Trường Đại học Ngoại ngũu, ĐHQGHN, \\ Phạm Văn Đồng, Cầu Giấy, Hà Nội, Việt Nam
}

Tóm tắt: Chiến lược học của sinh viên là một lĩnh vực quan trọng trong các nghiên cứu về giảng dạy tiếng Anh trong nhiều thập kỷ qua. Ở Việt Nam, trong khi vai trò của người giáo viên vẫn khó có thể thay thể, vẫn chưa có nhiều nghiên cứu về vai trò của người học và sự khác biệt giữa các đối tượng người học. Với sinh viên năm thứ nhất chuyên ngành tiếng Anh, vấn đề này càng cấp thiết vì họ phải đối mặt với những thay đổi sâu sắc và toàn diện trong phương pháp dạy và học tiếng Anh khi bước vào môi trường mới tại trường đại học. Nghiên cứu này được thực hiện trên 50 sinh viên chuyên ngành tiếng Anh tại một trường đại học ngoại ngữ ở Việt Nam với hai vấn đề: những chiến lược học nào đang được sử dụng, và có sự khác biệt nào giữa đối tượng sinh viên giỏi và sinh viên chưa giỏi sau một năm được hướng dẫn về chiến lược học viết. Nghiên cứu chỉ ra 4 nhóm chiến lược viết với tần suất sử dụng khác nhau và những khác biệt lớn trong việc sử dụng chiến lược học viết của sinh viên.

Tù khóa: hướng dẫn chiến lược học, chiến lược học, kỹ năng viết bằng tiếng Anh 